\title{
The Family: Crucial to and Divisive in Bioethics
}

\author{
恩格爾哈特
}

\section{摘要}

家庭是社會-生物學的實在, 有關如何適當地表述這種實在的 爭論劇烈, 處於文化戰爭之中心。本體-形上家庭觀認為, 家庭是 有規範性的社會實在, 父母子女具有給定的身份角色, 應當尊敬 祖先, 支持後代。這種家庭觀受傅統宗教（如基督教和儒教）所 推崇。自由主義家庭觀則認為, 家庭不過是其成員的創造, 應以 平等自由的觀念為主導, 因而各種類型的家庭均無不可。這兩種 不同的家庭觀對於生命倫理的重大問題, 及其相關公共政策䋥涵 不同的處理方式, 關涉人類生活的未來。

\section{【關鍵字】生命倫理 家庭 家庭同意 家庭帳戶}

\section{The Centrality of the Family for Bioethics}

The family is a phenomenon that occasions profound social and political controversy. It is central to the culture wars, because it bears on disputes about how one should form families and reproduce. Most people will agree that, as a socio-biological fact of the matter, humans tend to

恩格爾哈特, 美國萊斯大學哲學系教授, 美國。

《中外醫學哲學》XI:2 (2013 年) : 頁 113-127。

(C) Copyright 2013 by Global Scholarly Publications. 
form sexual-reproductive pairs. The family is a socio-biological reality. How to characterize this phenomenon is, however, a matter of significant disagreement. Is there a structure that all families should try to realize, or is it the case that humans can structure the family as they wish without important social and moral costs ${ }^{1}$ ? In this essay, this latter possibility is termed the libertarian-liberal account. The account is liberal, insofar as the free formation of the family is valued because it is held to enhance the liberty and/or the equality of the men, women, and children involved. It is libertarian insofar as individual freedom is regarded as a side constraint supporting the right and authority of persons to constitute families as they choose. The family seen as achieving a pre-existing social possibility with a moral claim for its realization is in this article termed the ontological or metaphysical account of the family. This ontological or metaphysical account is prominent in Confucianism ${ }^{2}$, as well as in traditional Judaism, Christianity, and Islam. In this account, the reality and good of the family are not reducible to the reality and good of its individual members. Also, in this account the roles of men, women, and children cannot be freely created, but are held properly to reflect antecedent, non-socially-constructed moral norms, a normative reality that supports status obligations within the family. These two competing proposals for understanding the socio-biological reality of human sexual and/or reproductive pairing and the family fuel the culture wars ${ }^{3}$. The goal of this essay is to lay out what distinguishes these two accounts, along with their different implications, especially for bioethics.

The account one gives of the family has implications for bioethics, in particular for medical decision-making and health care financing. For example, whether one turns to each individual family member for healthcare decision-making, or whether one turns to the family as a whole, depends on one's view of the autonomy and integrity of the family. The libertarian/liberal account regards each competent person as an independent individual who should exercise independent authority to make medical decisions. The ontological or metaphysical account regards individuals within a family like citizens within a county, bound together by obligations and an identity that authorizes the family on the model of the state to speak on behalf of its members. Depending on whether families or individuals are taken to be the usual source of authority for

(1) H. Tristram Engelhardt, Jr., "Beyond the Best Interests of Children: Four Views of the Family and of Foundational Disagreements Regarding Pediatric Decision Making," Journal of Medicine and Philosophy, 35:5 (Oct 2010), pp.499-517.

(2) FAN Ruiping (范瑞平) ed., The Renaissance of Confucianism in Contemporary China (Dordrecht; New York: Springer, 2011); FAN Ruiping, Reconstructionist Confucianism: Rethinking Morality after the West (Dordrecht; London: Springer, 2010).

(3) James Davison Hunter, Culture Wars (New York: Basic Books, 1991). 
healthcare decision-making, the burden of proof will favor keeping individual medical information confidential, or sharing it within the family. For defenders of the libertarian/liberal account, persons will be presumed rationally and/or actually to want to be treated as independent decision-makers unless they indicate that they wish to be treated as members of a family. For defenders of the ontological or metaphysical account, individuals will be treated as members of a family, with the family speaking on its members' behalf unless those members effectively express wishes to the contrary. So, too, the more one values the family, the more one should favor family-oriented health savings accounts (HSAs), which not only enhance the financial resources of the family, but which also encourage the family to function as a competent whole. If one favors the ontological or metaphysical account, one will endorse family-oriented HSAs that support the family as a social reality ${ }^{4}$. If one favors the liberal account, one will favor individual HSAs merely to enhance the liberty of individuals.

The ontological or metaphysical account and the libertarian/liberal account also favor conflicting views regarding the status of children ${ }^{5}$. Given the centrality of freedom as a side-constraints and/or freedom as a value, the libertarian/liberal account of children requires recognizing the decisional capacity of children as soon as feasible. In this account, the burden of proof lies on those who deny choice to the child. This approach leads to policies that favor the child's assent to treatment, if possible, around the age of seven and after, and then consent around the age of fourteen and after. It supports a robust doctrine of the mature minor, the view that early adolescents can be, and should be, respected in making decisions, as one would a competent adult ${ }^{6}$. In contrast, the ontological/metaphysical account places children, as well as all members of the family, within family authority. This view tends at the minimum to be that, as long as one is under the family's roof, one is under the family's authority. In its more developed forms, this view recognizes that individuals flourish best, and are best understood, within families. With regard to a child, it tends to favor a paternalistic approach to adolescents as not yet being able to make medical decisions as do persons of age. The

(4) Jeffrey P. Bishop, "Families, Dependencies, and the Moral Ground of Health Savings Accounts," Journal of Medicine and Philosophy, 37:6 (Dec 2012), pp.513-525.

(5) David Archard \& Colin M. Macleod eds. The Moral and Political Status of Children: New Essays (Oxford; New York: Oxford University Press, 2002).

(6) C. A. Cooper, "Emancipation of Minors," Journal of Juvenile Law, 8 (1984), pp.428-434; Susan D. Hawkins, "Protecting the Rights and Interests of Competent Minors in Litigated Medical Treatment Disputes,” Fordham Law Review, 64 (1996), pp.2075-2132; Joan Margaret Kun, "Rejecting the Adage Children should be Seen and not Heard - the Mature Minor Doctrine,” Pace Law Review, 16:2 (1996), pp.423-462; Lawrence P. Wilkins, "Children's Rights: Removing the Parental Consent Barrier to Medical Treatment of Minors,” Arizona State Law Journal, 1 (1975), pp.31-92. 
result of the ontological/metaphysical account is to shift the burden of proof in favor of the family's authority.

\section{The Libertarian-Liberal Account of the Family}

In many parts of the developed world, non-traditional forms of the family have become salient, along with traditional family structures being dramatically undermined. This transformation has occurred through the de facto embrace of a libertarian/liberal account of individual authority. In the pursuit of equality and freedom, individuals have been encouraged freely to structure sexual and/or reproductive pairing as they are inclined. Not only is the libertarian-liberal account at peace with the increasing phenomenon in the West of reproduction outside of marriage, but it also supports feminist construals of the family and defenses of homosexual marriage. For the libertarian/liberal account, the family is what consenting adults make of it. This view of the family is increasingly a part of the social reality in the West. For example, in the United States in 1960, only $5 \%$ of children were born outside of marriage. By 2011, this had risen to $40.7 \%{ }^{7}$. Similar transformations have taken place in Western Europe. As Charles Murray has shown in his recent study, Coming Apart: The State of White America 1960-2010, this transformation in the United States characterizes the lower, much more than the higher, socio-economic classes $^{8}$.

The libertarian/liberal account of the family undergirds either the view that there is no natural form of the family so that family structure comes about through the agreement of the participants, or alternatively the view that there is a natural form, which is individualistic in nature, because it reflects natural rights of individuals to free choice, equality, etc. In the latter case, post-traditional family structures are in harmony with the ethos of progressive, liberal, social-democratic states. In the former case, individuals qua individuals are regarded as the foundation of social structures in general and the family in particular. In either case, there is an accent on the pursuit of individual self-fulfillment in preference to the flourishing of the family as a whole. This leads to an undermining of an intergenerational view of the family in which one generation cares for the

(7) Brady E. Hamilton et al., "Births: Preliminary Data for 2011," National Vital Statistics Reports, 61 (2012), p.7 (Table 1); Also available at Centers for Disease Control and Prevention (U.S. Government), "FastStats: Unmarried Childbearing (data for 2011)," accessed on 16 September, 2013: http://www.cdc.gov/nchs/fastats/unmarry.htm; Stephanie J. Ventura \& Christine A. Bachrach, "Nonmarital Childbearing in the United States, 1940-99,” National Vital Statistics Reports, 48:16(2000) (Hyattsville, Maryland: National Center for Health Statistics), p.17 (Table 1).

(8) Charles Murray, Coming Apart: The State of White America, 1960-2010 (New York: Crown Forum, 2013). 
previous generation and seeks to support the families of its progeny. Because there is no commitment to the integrity of the family, divorce or a series of freely chosen partners is easily accepted, and reproduction outside marriage is affirmed.

Because the participants in the family are held to be free to decide what burdens they will individually accept, the appreciation of burdens and benefits is individually directed. As a consequence, given the burden involved in raising children, the ethos of this libertarian/liberal account has been associated with a dramatic drop in reproductive rates throughout the developed world. With no obligation to, and decreased interest in, future generations, increasingly fewer children are born. In addition, because of the commitment to freedom as a side constraint and/or liberty as a value, the libertarian/liberal account of the family, which supports feminist construals of the family, recognizes no natural role for men and women. Most significantly, the family is not considered to have an independent reality as a social structure apart from the individuals who constitute it, or to exist as an entity that naturally reaches into the long-range future. The moral life of the family as a consequence is not only individually directed, it involves in addition a hermeneutic of suspicion regarding the traditional family.

The habits of the heart that the libertarian/liberal construal of family encourages as virtues are those that characterize the contemporary, secular, quasi-post-modern world. The accent is on individual self-fulfillment and self-realization without a substantive account of what constitutes self-fulfillment, aside from an abstract commitment to autonomy, equality, and the self. In that the family is thinned to one generation, the libertarian/liberal account of the family has no necessary commitment to a family's long-range moral and financial family stability that can reach over generations. Further, the increase in reproduction outside of marriage has complex destabilizing implications. Fathers are not enrolled in the task of formal, long-term commitments to the women with whom they have sex and reproduce. The culture instead encourages an individualist pursuit of happiness. Increasingly, children are raised without the presence of two biological parents, in particular without the presence of a biological father. It is an age after the death of fathers. The number of families with only one parent present has increased from $9 \%$ in 1960 to $27 \%$ in $2010^{9}$. The libertarian/liberal account, given its abstract commitment to freedom, liberty, and equality, has no necessary concrete narrative of parenting and family. As Charles Murray has pointed out, in the United States this has led to a weakening of the mores that support the fabric of families ${ }^{10}$.

(9) W. Bradford Wilcox \& Elizabeth Marquardt, The State of Our Unions 2011: Marriage in America (Charlottesville: The National Marriage Project, 2011).

(10) Murray, Coming Apart: The State of White America, 1960-2010. 
Finally, the status of under-age children is a puzzle. In part, this is the case because the decision-making of persons under 21 tends to be qualitatively inferior to those who are older ${ }^{11}$. Despite the Convention on the Rights of the Child ${ }^{12}$ and the various political attempts to recognize adolescents as decision-makers, the challenge is how to characterize the conditions under which a child is a mature minor with the capacity of a decision-maker whose choices must be respected. Given the qualitative different character of the decision-making, maintaining the doctrine of the mature minor comes into difficulty ${ }^{13}$. At stake in particular is the extent to which, and under what circumstances, a relative lack of impulse control and of the ability to assess future risks as do adults, bring the decision-making of adolescents into question. Since these are always grey areas, the question is how in different circumstances one is to establish a particular burden of proof with a particular weight. For example, are 16-year-olds to be treated under the assumption that they are mature decision-makers with their own rights to privacy and individual decision-making until proven otherwise? The greater the claims of free choice, liberty, and equality, the greater the weight of the claims of children over against their families. Or are children to be considered as under parental authority until they ask to be treated otherwise and show their capacity? Does the status of the child and/or for that matter of fathers or mothers require that the child always be treated within the compass of the family? When the issue of the mature minor is approached as an empirical matter, much will turn not just on the issue of the actual decisional capacities of adolescents, but on the empirical issue as to

(11) Beatriz Luna et al., "What Has fMRI Told Us about the Development of Cognitive Control through Adolescence?” Brain and Cognition, 72:1 (Feb 2010), pp.101-113; Brian C. Partridge, "Adolescent Psychological Development, Parenting Styles, and Pediatric Decision-Making,” Journal of Medicine and Philosophy, 35:5 (Oct 2010), pp.518-525; Brian C. Partridge, "The Decisional Capacity of the Adolescent: An Introduction to a Critical Reconsideration of the Doctrine of the Mature Minor," Journal of Medicine \& Philosophy, 38:3 (Jun 2013), pp.249-255; Brian C. Partridge, "The Mature Minor: Some Critical Psychological Reflections on the Empirical Bases," Journal of Medicine \& Philosophy, 38:3 (Jun 2013), pp.283-299; Laurence Steinberg, "Does Recent Research on Adolescent Brain Development Inform the Mature Minor Doctrine?” Journal of Medicine \& Philosophy, 38:3 (Jun 2013), pp.256-267; Evan A. Wilhelms \& Valerie F. Reyna, "Fuzzy Trace Theory and Medical Decisions by Minors: Differences in Reasoning between Adolescents and Adults," Journal of Medicine \& Philosophy, 38:3 (Jun 2013), pp.268-282.

(12) United Nations, Convention on the Rights of the Child (1989/1990). Accessed on 12 September, 2013: http://www.ohchr.org/EN/ProfessionalInterest/Pages/CRC.aspx.

(13) Mark J. Cherry, "Ignoring the Data and Endangering Children: Why the Mature Minor Standard for Medical Decision Making must be Abandoned," Journal of Medicine and Philosophy, 38:3 (Jun 2013), pp.315-331; Partridge, "The Decisional Capacity of the Adolescent: An Introduction to a Critical Reconsideration of the Doctrine of the Mature Minor", pp.249-255; Partridge, "The Mature Minor: Some Critical Psychological Reflections on the Empirical Bases”, pp.283-299. 
whether authoritarian and authoritative parenting enhances the likelihood that children will grow into being responsible adults able to choose in a mature fashion ${ }^{14}$. The position one in the end takes depends crucially on the status of the moral authority of the family.

\section{The Ontological or Metaphysical Account of the Family}

The ontological or metaphysical account supports the traditional roles of husbands, wives, and children in the family. Obviously, there is no agreement as to the nature of those roles, but the force of the metaphysical account is that these roles are to be discovered, not created. They are a pre-existing, normative possibility. The family is recognized as an independent social reality that has an autonomy, integrity, and moral standing of its own. This autonomy, integrity, and moral standing support families being involved in medical decision-making on behalf of their members ${ }^{15}$. That is, family members are appreciated as primarily nested within the life and sovereignty of the family, a point of particular emphasis in Confucian accounts ${ }^{16}$. This view of the family allows deception in appropriate circumstances ${ }^{17}$. It also means that the family possesses an independent claim to financial sustainability. This autonomy and integrity can defeat some claims of the state over against the family and its members, insofar as the family is recognized as having an independent moral status and sovereignty, especially with regard to the family consenting to treatment on behalf of its members ${ }^{18}$. The social category of the family encourages the maintenance and function of the family as a

(14) Partridge, “Adolescent Psychological Development, Parenting Styles, and Pediatric Decision-Making”, pp.518-525; Laurence Steinberg et al., "Impact of Parenting Practices on Adolescent Achievement: Authoritative Parenting, School Involvement, and Encouragement to Succeed,” Child Development, 63:5 (Oct 1992), pp.1266-1281.

(15) FAN Ruiping (范瑞平) \& Julia Tao (陶黎寶華), “Consent to Medical Treatment: The Complex Interplay of Patients, Families, and Physicians,” Journal of Medicine and Philosophy, 29:2 (Apr 2004), pp.139-148.

(16) CHEN Xiaoyang (陳曉陽) \& FAN Ruiping (范瑞平), “The Family and Harmonious Medical Decision Making: Cherishing an Appropriate Confucian Moral Balance," Journal of Medicine and Philosophy, 35:5 (Oct 2010), pp.573-586; FAN Ruiping, "Which Care? Whose Responsibility? And Why Family? A Confucian Account of Long-Term Care for the Elderly,” Journal of Medicine and Philosophy, 32:5 (Oct 2007), pp.495-517.

(17) FAN Ruiping (范瑞平) \& LI Benfu (李本富), “Truth Telling in Medicine: The Confucian View,” Journal of Medicine and Philosophy, 29:2 (Apr 2004), pp.179-194.

(18) WANG Mingxu (王明旭), LO Ping-Cheung (羅秉祥) \& FAN Ruiping (范瑞平), "Medical Decision Making and the Family: An Examination of Controversies," Journal of Medicine \& Philosophy, 35:5 (Oct 2010), pp.493-498. 
robust and quasi-independent social unit ${ }^{19}$. The substance of the family as a social reality will importantly turn on the concrete view of familial flourishing, which the family endorses. The very presence of a family-centered focus will tend to undermine a view of the family that encourages purely individually-directed behavior.

The family's character depends on the family supporting habits of behavior such as mutual regard, self-sacrifice, mutual support, and an understanding of a common future. In fact, the family as a social reality encourages an experience of the family as living over time. The present is expanded to reach back with gratitude to ancestors, and to the future in support of descendants. The family in this way promotes a complex socialization of its members that requires them to be willing to forgo personal advantage in order to advance the interests of the family as a whole. This family-centered other-directedness presupposes a moral vision radically different from that encouraged by the libertarian/liberal account of the family. It is not just that a more than one generational view of the family is nourished, but that the habits of the heart necessary to sustain this structure are also nurtured. The outcome of all of this is that the ontological or metaphysical view of the family acts to endorse a web of other-directed virtues, along with the accumulation of social capital.

The traditional family in societies that celebrate its existence has been associated with not only the preservation of social capital but also with the creation of financial capital. Families tend in general to save in order to preserve and enhance their own positions. In health care, such savings can be encouraged through healthcare savings accounts, especially through those that are family-oriented ${ }^{20} .{ }^{21}$ Here one should in particular think of such countries as Singapore, which have encouraged health savings accounts that have important family-oriented features in allowing the transfer of resources within the family to meet familial health

(19) LI Jun (李俊) \& WANG Jue (王珏), “Individuals are Inadequate: Recognizing the Family-Centeredness of Chinese Bioethics and Chinese Health System," Journal of Medicine and Philosophy, 37:6 (Dec 2012), pp.568-582.

(20) Mark J. Cherry, "Building Social and Economic Capital: the Family and Medical Savings Accounts," Journal of Medicine and Philosophy, 37:6 (Dec 2012), pp.526-544.

(21) The accumulation of resources is encouraged by ordinary health savings accounts (HSAs). "With MSAs [i.e., HSAs], therefore, workers would effectively be spending their own funds for noncatastrophic health care. As a result, they would have full market incentives to control the costs of such care. They would seek to avoid unnecessary care or tests and look for doctors and hospitals that would provide good quality care at the best prices. That, in turn, would stimulate true cost competition among doctors and hospitals. Since consumers would be choosing on the basis of cost as well as quality, providers would compete to minimize costs as well as maximize quality, as in a normal market.” See Peter J. Ferrara, "More than a Theory: Medical Savings Accounts at Work," Policy Analysis (Cato Institute), No. 220 (Washington, D.C.: Cato Institute, 1995). The more that HSAs have a focus on family-oriented savings, the more society at large is not burdened with the expenses of family members. 
care needs ${ }^{22} \cdot{ }^{23}$ In addition, this accumulation of capital has been beneficial for the society generally by encouraging families to care for themselves. This not only diminishes the need for social welfare, but also accumulates economic resources that can support the development of the society as a whole $\mathrm{e}^{24}$.

The traditional family thus functions importantly as an intermediate institution between the individual and the state, able to promote the moral, emotional, and social support of its members. The web of socialization that results encourages the stability and sustainability of society. For example, in the United States, the decline of the traditional family is correlated with an increase in problems with drug addiction and criminality that have become especially prominent when the family thins to a single mother with her children. ${ }^{25}$ In the last case, the differences are frequently so stark that the contrast is between functionality and dysfunctionality. Again, the successes of the traditional family are achieved by means of important trade-offs between an immediate pursuit of individual satisfaction and the pursuit of the good of other members of

(22) LIM Meng-Kin (林明健), “Values and Health Care: The Confucian Dimension in Health Care Reform,” Journal of Medicine and Philosophy, 37:6 (Dec 2012), pp.545-555.

(23) Singapore has successfully engaged medical savings accounts (Medisave) as a central component in their health care system in order to contain costs as well as to build social and economic capital. See Central Provident Fund Board (Singapore Government), "Understanding Medisave And MediShield," accessed on 16 September, 2013: http://mycpf.cpf.gov.sg/CPF/my-cpf/Healthcare/PvdHC3.htm. See also William C. Hsiao, "Medical Savings Accounts: Lessons from Singapore," Health Affairs, 14:2 (Summer 1995), pp.260-266.

(24) FAN Ruiping (范瑞平) et al., “Family-Oriented Health Savings Accounts: Facing the Challenges of Health Care Allocation," Journal of Medicine and Philosophy, 37:6 (Dec 2012), pp. 507-512.

(25) The presence in a family of both biological parents appears to be positively associated with the well-being of the children. "No matter what the outcome being examined - the quality of the mother-infant relationship, externalizing behavior in childhood (aggression, delinquency, and hyperactivity), delinquency in adolescence, criminality as adults, illness and injury in childhood, early mortality, sexual decision making in adolescence, school problems and dropping out, emotional health, or any other measure of how well or poorly children do in life - the family structure that produces the best outcomes for children, on average, are two biological parents who remain married. Divorced parents produce the next-best outcomes. Whether the parents remarry or remain single while the children are growing up makes little difference. Never-married women produce the worst outcomes. All of these statements apply after controlling for the family's socio-economic status" (Murray, Coming Apart: The State of White America, 1960-2010, p.158). 
the family. ${ }^{26}$ The traditional family takes on its character by locating its members within an intertwining fabric of obligations and claims.

Given these circumstances, everything looks different within the traditional family. The traditional family runs against the grain of a post-traditional culture ${ }^{27}$. In addition, the traditional family supports a hermeneutic of suspicion regarding the libertarian/liberal account of the family, which attempts to treat individuals as in their roots atomic, isolated sources of free choice, rather than to regard persons as rich with roles and status due to intrafamilial obligations. The libertarian/liberal account acts as if the status of individuals within families reflected no already-existing roles and obligations. Instead, the libertarian/liberal account regards all familial roles as created by individual humans and as fully fungible. In contrast, the traditional view of the family recognizes persons as properly nested in families that are shaped by pre-existing roles for their members, such as father and mother, husband and wife, parent and child. The result is that being an isolated individual is regarded as a deviation that is realized over and against the family.

In summary, those who live within families structured in terms of a traditional ontological or metaphysical view of the family live in a life-world significantly different from those who embrace a libertarian and/or liberal view of the family. Among the differences is the circumstance that persons within a traditional family that presupposes an ontological or metaphysical grounding for its claims see themselves

(26) Single-parent households are associated with adverse outcomes for children. "Children raised in single-parent households are, on average, more likely to be poor, to have health problems and psychological disorders, to commit crimes and exhibit other conduct disorders, have somewhat poorer relationships with both family and peers, and as adults eventually get fewer years of education and enjoy less stable marriages and lower occupational statuses than children whose parents got and stayed married. This 'marriage gap' in children's well-being remains true even after researchers control for important family characteristics, including parents' race, income, and socioeconomic status” See Linda J. Waite \& Maggie Gallagher, The Case for Marriage: Why Married People are Happier, Healthier, and Better off Financially (New York: Doubleday, 2000), p.125. See also Jeffrey T. Cookston, "Parental Supervision and Family Structure: Effects on Adolescent Problem Behaviors," Journal of Divorce and Remarriage, 31:1/2 (Dec 1999), pp.107-127; Patrick F. Fagan \& Robert Rector, "The Effects of Divorce on America," The World \& I, 15:10 (Oct 2000), pp. 56-61; Daniel S. Shaw et al., "A Prospective Study of the Effects of Marital Status and Family Relations on Young Children's Adjustment among African American and European American Families,” Child Development, 70:3 (May-Jun 1999), pp.742-755; D. Wayne Osgood \& Jeff M. Chambers, "Social Disorganization outside the Metropolis: An Analysis of Rural Youth Violence,” Criminology, 38:1 (Feb 2000), pp. 81-115; Toby L. Parcel \& Mikaela J. Dufur, "Capital at Home and at School: Effects on Student Achievement," Social Forces, 79:3 (Mar 2001), pp.881-911; Pamela Wilcox Rountree \& Barbara D. Warner, "Social Ties and Crime: Is the Relationship Gendered?” Criminology, 37:4 (Nov 1999), pp.789-813.

(27) H. Tristram Engelhardt, Jr., "Fair Equality of Opportunity Critically Reexamined: the Family and the Sustainability of Health Care Systems," Journal of Medicine and Philosophy, 37:6 (Dec 2012), pp.583-602. 
anchored in the very structure of reality. Because of a remembrance of ancestors and a commitment to long-range descendants, the present is fattened by being bound to a past and a future. The family that regards itself as achieving a social reality rich in virtues exercised over time tends to encompass great-grandparents in memory and great-grandchildren in anticipation. The family in this account reaches to people long dead and persons unborn. The everyday behavior and moral concerns of the family as an ontological or metaphysical reality collides with libertarian-liberal accounts.

\section{The Family, Bioethics, and the Culture Wars}

The traditional family, which is supported by the ontological-metaphysical account, collides with many of the commitments of the liberal social-democratic state, particularly its egalitarian aspirations ${ }^{28}$. Families are divisive. They support the well-being of their own family members in a way that does not embrace the principle of equality of opportunity. They seek to secure for their own members more opportunities. Regarding the family as an independent and autonomous social reality also establishes a social identity independent of the larger community and the state. In addition, families can work across national borders and see their interests as independent of and transcending those of the state. In contrast, the libertarian-liberal account of the family does not erect a border of familial autonomy between individuals and the state. Indeed, when deprived of strong familial support, often individuals must by default turn to governmental agencies for support, nurture, and direction. This state of affairs is complex and, as already noted, is associated with the loss of social and financial capital ${ }^{29}$. Finally, while noting societal trends that undermine traditional family structures, it should be stressed that some forms of the traditional family appear relatively immune to contemporary transformative social forces. One might think of the flourishing of Hasidic Jews in the heart of New York City $^{30}$. Such families thrive, although they support values at odds with the libertarian-liberal tolerance and/or affirmation of homosexual marriage, reproduction outside of wedlock, and the presumption of the autonomy of individuals apart from families. As already observed, these differences have dramatic implications regarding who is asked to make medical decisions, how children are treated, and how one approaches the

(28) Engelhardt, "Fair Equality of Opportunity Critically Reexamined: the Family and the Sustainability of Health Care Systems”, pp.583-602.

(29) Murray, Coming Apart: The State of White America, 1960-2010.

(30) Ayala Fader, Mitzvah Girls: Bringing up the Next Generation of Hasidic Jews in Brooklyn (Princeton, NJ: Princeton University Press, 2009). 
challenges of the financial sustainability of a healthcare system or even of society in general. The implications of the differences for bioethics and healthcare policy are significant.

In reflecting on the family and looking to the future, one confronts the major cultural task of honestly assessing the social, financial, and moral costs involved in an increased presence of post-traditional families. As long as a sufficient core of traditional families remains, the costs of recent changes may not be fully apparent. One has yet to experience what society will be like when a significant proportion of its members are from the third generation of single-parent households. It is also far from clear what the financial, social, and moral costs of such a state of affairs will be. At stake are vastly different ways of regarding morality, the meaning of life, and the proper conduct of bioethics. Reflections on how to respond to these developments should be a matter of concern for polities where traditional family structures are still relatively intact, such as China, Korea, and Singapore. The conflict between the libertarian-liberal account of the family and the ontological-metaphysical account of the family is at the heart of the culture wars.

\section{參考文獻}

Archard, David \& Colin M. Macleod eds. The Moral and Political Status of Children: New Essays (Oxford; New York: Oxford University Press, 2002).

Bishop, Jeffrey P. "Families, Dependencies, and the Moral Ground of Health Savings Accounts.” Journal of Medicine and Philosophy 37:6 (Dec 2012), pp.513-525.

Centers for Disease Control and Prevention (U.S. Government). "FastStats: Unmarried Childbearing (data for 2011)." Accessed on 16 September, 2013: http://www.cdc.gov/nchs/fastats/unmarry.htm.

Central Provident Fund Board (Singapore Government). "Understanding Medisave And MediShield." Accessed on 16 September, 2013: http://mycpf.cpf.gov.sg/CPF/my-cpf/Healthcare/PvdHC3.htm.

Chen, Xiaoyang (陳曉陽) \& FAN Ruiping (范瑞平). “The Family and Harmonious Medical Decision Making: Cherishing an Appropriate Confucian Moral Balance.” Journal of Medicine and Philosophy 35:5 (Oct 2010), pp.573-586.

Cherry, Mark J. "Ignoring the Data and Endangering Children: Why the Mature Minor Standard for Medical Decision Making must be Abandoned." Journal of Medicine and Philosophy 38:3 (Jun 2013), pp.315-331.

Cherry, Mark J. "Building Social and Economic Capital: the Family and Medical Savings Accounts.” Journal of Medicine and Philosophy 37:6 (Dec 2012), pp.526-544. 
Cookston, Jeffrey T. "Parental Supervision and Family Structure: Effects on Adolescent Problem Behaviors.” Journal of Divorce and Remarriage 31:1/2 (Dec 1999), pp.107-127.

Cooper, C. A. “Emancipation of Minors.” Journal of Juvenile Law 8 (1984), pp.428-434.

Engelhardt, Jr., H. Tristram. "Fair Equality of Opportunity Critically Reexamined: the Family and the Sustainability of Health Care Systems.” Journal of Medicine and Philosophy 37:6 (Dec 2012), pp.583-602.

Engelhardt, Jr., H. Tristram. "Beyond the Best Interests of Children: Four Views of the Family and of Foundational Disagreements Regarding Pediatric Decision Making.” Journal of Medicine and Philosophy 35:5 (Oct 2010), pp.499-517.

Fader, Ayala. Mitzvah Girls: Bringing Up the Next Generation of Hasidic Jews in Brooklyn (Princeton, NJ: Princeton University Press, 2009).

Fagan, Patrick F. \& Robert Rector. "The Effects of Divorce on America.” The World \& I 15:10 (Oct 2000), pp. 56-61.

Fan, Ruiping (范瑞平). Reconstructionist Confucianism: Rethinking Morality after the West (Dordrecht; London: Springer, 2010).

Fan, Ruiping (范瑞平) ed. The Renaissance of Confucianism in Contemporary China (Dordrecht; New York: Springer, 2011).

Fan, Ruiping (范瑞平). “Which Care? Whose Responsibility? And Why Family? A Confucian Account of Long-Term Care for the Elderly.” Journal of Medicine and Philosophy 32:5 (Oct 2007), pp.495-517.

Fan, Ruiping (范瑞平), CHEN Xiaoyang (陳曉陽) \& CAO Yongfu (曹永福). "Family-Oriented Health Savings Accounts: Facing the Challenges of Health Care Allocation.” Journal of Medicine and Philosophy 37:6 (Dec 2012), pp.507-512.

Fan, Ruiping (范瑞平) \& LI Benfu (李本富). “Truth Telling in Medicine: The Confucian View.” Journal of Medicine and Philosophy 29:2 (Apr 2004), pp.179-194.

Fan, Ruiping (范瑞平) \& Julia Tao（陶黎寶華）. “Consent to Medical Treatment: The Complex Interplay of Patients, Families, and Physicians.” Journal of Medicine and Philosophy 29:2 (Apr 2004), pp.139-148.

Ferrara, Peter J. “More than a Theory: Medical Savings Accounts at Work.” Policy Analysis (Cato Institute), No. 220 (Washington, D.C.: Cato Institute, 1995).

Hamilton, Brady E., Joyce A. Martin \& Stephanie J. Ventura. “Births: Preliminary Data for 2011.” National Vital Statistics Reports 61:5 (2012) (Hyattsville, MD: National Center for Health Statistics), pp.1-19.

Hawkins, Susan D. "Protecting the Rights and Interests of Competent Minors in Litigated Medical Treatment Disputes.” Fordham Law Review 64 (1996), pp.2075-2132.

Hsiao, William C. “Medical Savings Accounts: Lessons from Singapore.” Health Affairs 14:2 (Summer 1995), pp.260-266.

Hunter, James Davison. Culture Wars (New York: Basic Books, 1991).

Kun, Joan Margaret. "Rejecting the Adage Children should be Seen and not Heard - the Mature Minor Doctrine.” Pace Law Review 16:2 (1996), pp.423-462. 
Li, Jun (李俊) \& WANG Jue (王珏). “Individuals are Inadequate: Recognizing the Family-Centeredness of Chinese Bioethics and Chinese Health System.” Journal of Medicine and Philosophy 37:6 (Dec 2012), pp.568-582.

Lim, Meng-Kin (林明健). “Values and Health Care: The Confucian Dimension in Health Care Reform.” Journal of Medicine and Philosophy 37:6 (Dec 2012), pp.545-555.

Luna, Beatriz, Aarthi Padmanabhan \& Kirsten O’Hearn. “What Has fMRI Told Us about the Development of Cognitive Control through Adolescence?” Brain and Cognition 72:1 (Feb 2010), pp.101-113.

Murray, Charles. Coming Apart: The State of White America, 1960-2010 (New York: Crown Forum, 2013).

Osgood, D. Wayne \& Jeff M. Chambers. "Social Disorganization outside the Metropolis: An Analysis of Rural Youth Violence.” Criminology 38:1 (Feb 2000), pp. 81-115.

Parcel, Toby L. \& Mikaela J. Dufur. "Capital at Home and at School: Effects on Student Achievement.” Social Forces 79:3 (Mar 2001), pp.881-911.

Partridge, Brian C. “Adolescent Psychological Development, Parenting Styles, and Pediatric Decision-Making.” Journal of Medicine and Philosophy 35:5 (Oct 2010), pp.518-525.

Partridge, Brian C. "The Decisional Capacity of the Adolescent: An Introduction to a Critical Reconsideration of the Doctrine of the Mature Minor.” Journal of Medicine \& Philosophy 38:3 (Jun 2013), pp.249-255.

Partridge, Brian C. “The Mature Minor: Some Critical Psychological Reflections on the Empirical Bases.” Journal of Medicine \& Philosophy 38:3 (Jun 2013), pp.283-299.

Rountree, Pamela Wilcox \& Barbara D. Warner. "Social Ties and Crime: Is the Relationship Gendered?” Criminology 37:4 (Nov 1999), pp.789-813.

Shaw, Daniel S., Emily B. Winslow \& Clare Flanagan. "A Prospective Study of the Effects of Marital Status and Family Relations on Young Children's Adjustment among African American and European American Families.” Child Development 70:3 (May-Jun 1999), pp.742-755.

Steinberg, Laurence. "Does Recent Research on Adolescent Brain Development Inform the Mature Minor Doctrine?” Journal of Medicine \& Philosophy 38:3 (Jun 2013), pp.256-267.

Steinberg, Laurence, Susie D. Lamborn, Sanford M. Dornbusch \& Nancy Darling. "Impact of Parenting Practices on Adolescent Achievement: Authoritative Parenting, School Involvement, and Encouragement to Succeed.” Child Development 63:5 (Oct 1992), pp.1266-1281.

United Nations. Convention on the Rights of the Child (1989/1990). Accessed on 12 September, 2013:

http://www.ohchr.org/EN/ProfessionalInterest/Pages/CRC.aspx.

Ventura, Stephanie J. \& Christine A. Bachrach. "Nonmarital Childbearing in the United States, 1940-99.” National Vital Statistics Reports 48:16(2000) (Hyattsville, Maryland: National Center for Health Statistics), pp.1-40.

Waite, Linda J. \& Maggie Gallagher. The Case for Marriage: Why Married People are Happier, Healthier, and Better off Financially (New York: Doubleday, 2000). 
Wang, Mingxu (王明旭), LO Ping-cheung (羅秉祥), \& FAN Ruiping (范瑞平). "Medical Decision Making and the Family: An Examination of Controversies.” Journal of Medicine \& Philosophy 35:5 (Oct 2010), pp.493-498.

Wilcox, W. Bradford \& Elizabeth Marquardt. The State of Our Unions 2011: Marriage in America (Charlottesville: The National Marriage Project, 2011).

Wilhelms, Evan A. \& Valerie F. Reyna. "Fuzzy Trace Theory and Medical Decisions by Minors: Differences in Reasoning between Adolescents and Adults.” Journal of Medicine \& Philosophy 38:3 (Jun 2013), pp.268-282.

Wilkins, Lawrence P. "Children’s Rights: Removing the Parental Consent Barrier to Medical Treatment of Minors.” Arizona State Law Journal 1(1975), pp.31-92. 